りころさらず，主として通電々流の大小に依存している ものと考党られる。

（3）液間電圧降下之隬膜厧の抵抗火上る電生降下の


なわち実際の電解槽汇招いてては，淂膜の陽極室側の境界 は判然としないので，上述の上うな方法で求めたのであ るが，䈌密には正しくない，しかし現埸管理用のデータ

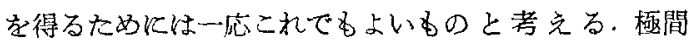
電压降下の構成因子である，液間電圧降下分上隔膜凮保 よる電圧降下分との経時変化をるる，極間電生に対し て占める制合湔前は 50〜60\%，後者は 50〜40\%であ った．浴電圧が電解槽の運転日数とともに上帠するのは 大部分極間電圧の上舁に起国しているから, 浴電任の上

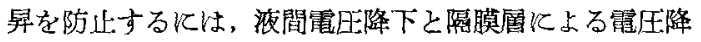
下とを小さくすべきである、具体的に言うと黑鉛の崩埴 をできるだけ少なくすること，执よび淂膜の目詰りを少 なくするといら点注意すべきであると思う。

（4）隄極液中の疏酸ナトリウム分，懸濁物賀（黑鉛 粒子, 気泡，水酸化物など) 食塩分の含有量の変化江上 る電導度の測定は今後の研究に待つベき点が多いと考方 る.

（5）Stender (3) の報告に上ると，隔膜部分飞括ける 電任降下は，隔膜 2 枚使用時江括いて，電流密度 8 9 $\mathrm{A} / \mathrm{dm}^{2}$ 特よび温度 $70^{\circ} \mathrm{C}$ で, 大略 $0.12 \sim 0.15 \mathrm{~V}$ 之言わ れているが，筆者らの測定に上ると，この值は一定でな

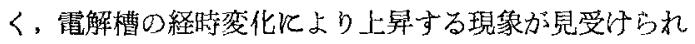
た、これは測定方法の相違基くものと考克られる。す なわち Stender は実験室の測定からえた結果である故, 経時的要因があまり入ら双とともに，黑鈆の崩壊した微 粒子括よび供給餉和食塩水中の不純物の影響等が異なる ためと考它られる。

(6) 測定場所，黒鉛板の頭部より約 $55 \mathrm{~cm}$ 下儿選 んだのは，黒鈆の電解にあずかる部分の中心部で測定で きるようにしたためである。

\section{5. 結 論}

（1）アーレン・ムーアーKML 型電解槽の麗王収支 の経時変化について調へた。

（2）その結果，陽極部分の筐主は新しい黑鉛を使用 した時は, 通電電流の変化にかわわらず, 運転日数とと あに濑次低下し，約 120 日閒で約 $0.15 \mathrm{~V}$ 低下した。し かし，一度使用した黒鉛を再び陽掼として使用した時は このような現象は見受けられなかった。

(3) 陰極部分の電任は, 主として, 通軖電流の大小 により, 変化するものと考克られる。

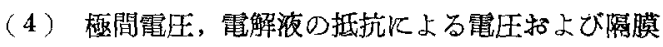
囷の抵抗による電压は，経時変化により，上昇する。特 に60日頃からの上昇偭问依高いよう飞見受けられた。

(5) 浴電圧の経時変化火よる上暑原因は，大部分は 極間電圧の上昇によるものと考えられる。


は，黑鉛の崩境を防ぐ方法上，隔膜の抵抗增加を防止す る方法とに考慮を払光ば良いことがわかった。

䅂りに臨又, 本研究を行うに当り，終始ご留篤なご指 尊を賜わった，東京大学，岡俊平教授ならびに横浜国立 大学, 松野武雄助教授に，深く感謝の意を表与。衣本 研究は，昭和 30 年执よび 31 年度の文部省科学試験研 究費に一部低存したことをあわせ剑謝する。

$$
\text { (昭 33-3-31 受理) }
$$

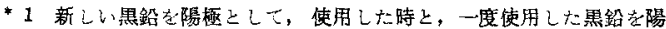



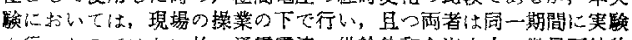
炎行ったので去ない故，通電電流，供給館和食弶水中の微量不純物

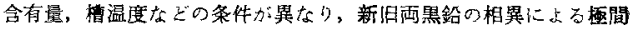

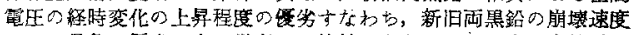


記载己た。
}

文献

(1) 大我膦躬：ソーダと湓索，6，209 (1955)



(3) W.W. Stender, P.B. Zivotinsky, M.M. Stroganoff : Trans. Electrochem. Soc., 65, 189 (1934)

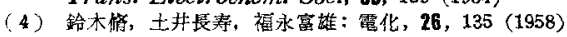

\title{
アルカリ溶液におけるチタンの陽極的挙動* Anodic Behavior of Titanium in Alkaline Solutions
}

\author{
F葉搏** \\ Hiroshi CHIBA
}

\section{1. 緒言}

チタンはごくわずかな電流によって車隄極的にきわわ

* チタンの陽栖的举勘に関方る研垫（第 1 報） Studies on the Anodic Behavior of Titanium (Part 1) 昭和 31 年4月 日本化学会 第 9 年会心て詳演

**日本電信電話公社電気通信研究所（武薜野市吉祥寺 1551）


この金属のすぐれて耐食性を示す大きな要因ともなって 扣り，更飞チ夕ン酸化物嵪い誘電率岁有することなど から，晹桠酸化飞上る酸化被膜形成について坆夷用上に も種々興味の女る所でる。

すでに Hall ら ${ }^{(1)} は$ 㙁化カリウム溶液中に括ける踢極 
的挙動飞ついて報告しているが，著者は酸化被膜形成似 関する研究の基礎として特にホウ酸ソーダ括よびカセイ ソーダなどのアルカリ浴液中に和ける挙動について，陽 極電位の時間的変化，溶液中の溶存酸素の影㗽特占び酸 素ガス発生の過電压について得られた結果について報告 する。

\section{2. 試料および実験方法}

（1）試料 試料金属は住友金属製（純度 $99.5 \%$ 以 上）の厚さ $2 \mathrm{~mm}$ のチタン板を真空焼ナマシ $0.2 \mathrm{~mm}$ に圧延壮るものを用いた。このチタン板を幅 $1 \mathrm{~cm}$, 高 さ $1 \mathrm{~cm}$ 老残し接着剤炕てガラス管に固定し䧕料電極と した. 試料はすべて実験直前化 04 番エメリ一紙で研磨 しエタノールて洗浄して用いた.溶液は $0.1 \mathrm{~N}$ ホウ酸り 一ダ拓よび $0.1 \mathrm{~N}$ カセイソーダ溶液をそれぞれ用いた。



$\mathrm{A}:$ 定電流柿置, $\mathrm{B}$ : 真空管電位差計, $\mathrm{C}:$ 白金極,

$\mathrm{D}$ : 試料, $\mathrm{E}$-蚫和甘コウ電極 第 1 図䒠験装置

（2）実験方法 実験装置を第 1 図に示した。電流の 負荷に関しては実験中起る表面被膜形成々の他飞基ら く陽極面上の抵抗招よび電位変化々か〉和らず，一定電 流を負荷しうるよう設計した真空管回路を用い，1２00 $\mu \mathrm{A} / \mathrm{cm}^{2}$ の間の各定電流密度に括ける電極電位の時閆的 変化を真空管電位差計を用いて湘定を行った．な括この 測定にはすべて飽和塩化加里甘コウ電極を照合電極とし て用い， $1.5 \mathrm{~V}$ 以上の電位測定については，あらかじめ

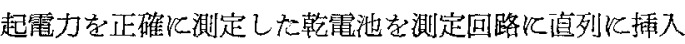
し，試料電極の電位を補償しつつ測定を行った，実騟温 度はすべて $25^{\circ} \mathrm{C}$ で行った。

\section{3. 実 験 結 果}

\section{1） $0.1 \mathrm{~N}$ ホウ酸ソータ溶液中の陽極電位変化}

溶液中の溶存酸素の陽極電位变化飞及住す影響を調べ る目的で，むらかじめ空気をじゅうぶれに飽和させた溶 液と公素ガスを通じて空気を置換させた溶液に扰ける電 位の時間的変化を第 2 図に示した. 図中の実線は空気飽 和の場合で, 破線は乿素ガスを通じた溶液に括ける変化

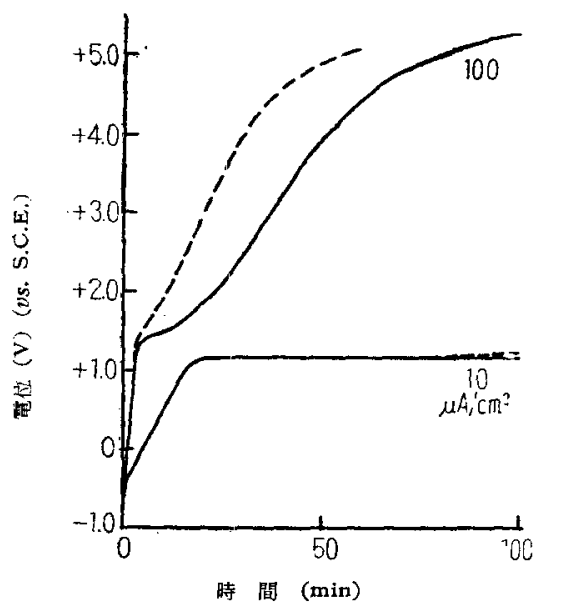

第 2 図電位一時間曲線飞及ほす溶存酸素の影響

で $10 \mu \mathrm{A} / \mathrm{cm}^{2}$ 拓よび $100 \mu \mathrm{A} / \mathrm{cm}^{2}$ の電流密度に和ける 実験結果を示した。この図に見るように， $+1.2 \mathrm{~V}$ 附近を 境として 2 段の電位上昇が現われるが, $+1.2 \mathrm{~V}$ 附近ま での電位変化には溶存酸素のうむは全く関係しないこと が認められる。しかしながら+1.2V附近を越してから


て溶存酸素を置换させた溶液中では $+1.2 \mathrm{~V}$ 附近に現わ れる電位の平坥部は短時間飞䅂り第 2 段の電位の上昇が 行われる.この $+1.2 \mathrm{~V}$ 附近に現われる電位変化の平 坦部分は電極面上り酸素がスの発生の始まる所と考光ら れ，以下の実験にはすべて空気をじゅうふんル館和させ た溶液を用いて行った。

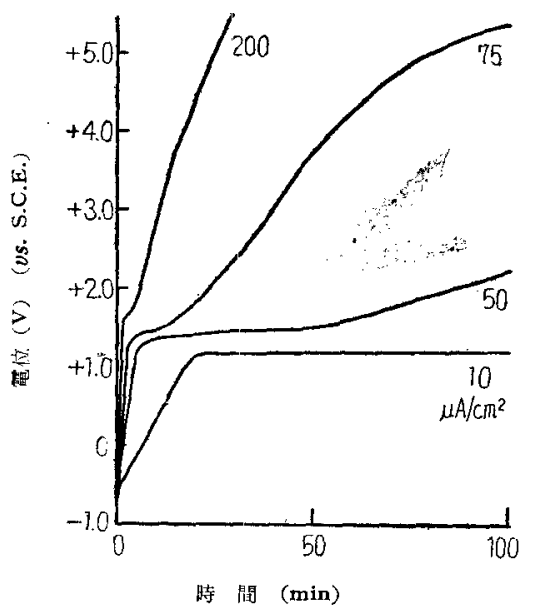

第 3 図 $0.1 \mathrm{~N}$ ホウ醁ソーダ中の電位一侍間曲線

第3図沙 $5 \sim 200 \mu \mathrm{A} / \mathrm{cm}^{2}$ の各定電流密度飞格ける陽 殹霄位の時間的変化の湘定結果を示した.いずれの場合 飞括いても，ごく初期の僅かな電位上暈の後は全く直線 的红変化を続け， $+1.2 \mathrm{~V}$ 附近である時間定常状態を示

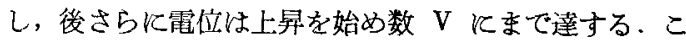


の変化は電流值の增加とともに怂速になり，したがって また途中に現われる電位の時間的に平坦な部分子短かく なって次の第 2 段の電位上昇に移行する＋ $+1.2 \mathrm{~V}$ 附近 の電位の定常状態に達した電極面には, 気泡の附着が見 られ，酸素ガス発生沃因るすのと認められる。

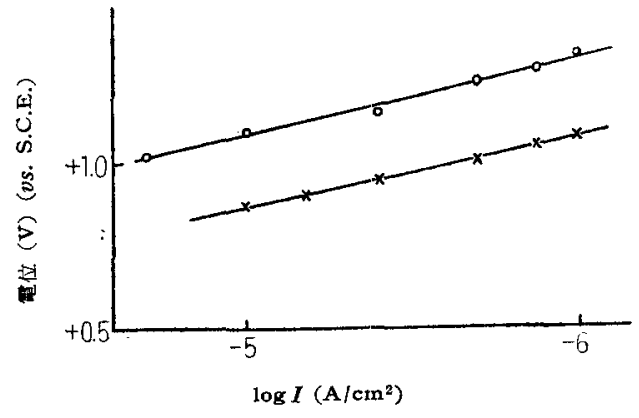

第 4 図 電位対 $\log I$ 図

な括この平坦部分に执いて示される電極電位値を電流 密度の対数についてとった結果学第 4 図に示した。この 電流密度の籍㘫で Tafel の直線関係が見られ，この直 線を表わす実験式

$$
E=2.19+0.22 \log I
$$

\section{ここに $I:$ 電流密度 $\left(\mathrm{A} / \mathrm{cm}^{2}\right)$}

を得る.次にこの溶液の $\mathrm{pH} 9.17$ から酸素発生の可逆 電位を求めると $0.44 \mathrm{~V}$ (S.C.E.) を得る. この可逆電 位を上の実験式上り引くと

$$
\eta=1.75+0.22 \log I
$$

を得る。クは酸素ガス発生過電圧を表わす.

\section{2） $0.1 \mathrm{~N}$ カセイソータ溶腹中の陽極電位変化}

$0.1 \mathrm{~N}$ カセイソーダ溶液飞抢汀る陽極的挙動は, 亦口 酸ソーダ溶液中に扣ける場合上本質的に同様な挙動方示 し、溶液中の溶存酸素の影響方同一電流密度下では常に 空気䬶和の溶液で酸素発生後の第 2 段の電位上昇はす みやかに行われることが認められた。第 5 図に 10〜200

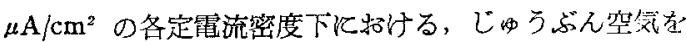
飽和させた $0.1 \mathrm{~N}$ カセイソ一ダ溶液中の陽極電位の時 間的変化を示した。電位変化はホウ酸りーダ溶液中に招 ける場合と同じ上ろに $1 \mathrm{~V}$ 附近飞生じる電位変化の平

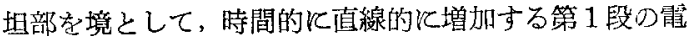
位变化部と酸素発生を伴う第 2 段の変化の 2 つの電位上 㫒が見られる。またこの酸素ガス発生による電位変化の

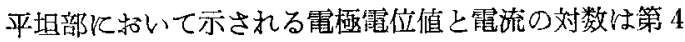
図以示すような直線関係が得られた。

\section{この直線関係より電位値を表わす式として}

$$
E=1.87+0.20 \log I
$$

$$
\text { ここK } I: \text { 電流密度 }\left(\mathrm{A} / \mathrm{cm}^{2}\right)
$$

を得る。この溶液の $\mathrm{pH} 13.0$ 飞沏ける酸素発生の可逆


ける酸素発生過電压を表わす式として

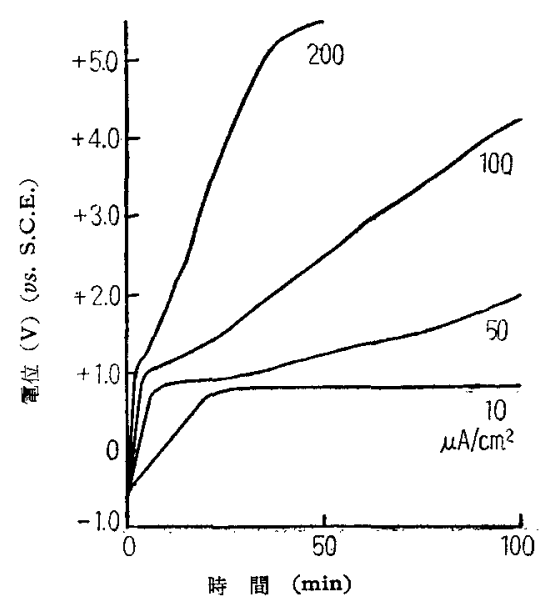

第 5 図 $0.1 \mathrm{~N}$ カセイソーダ中の䉛位一時間曲線

$$
\eta=1.66+0.20 \log I \text { 老得た. }
$$

\section{4. 考察}

チタンのこれら溶液中に却ける陽極電位の時間的変化 络次の3つの部分に分けて考克ることが出来る。すなわ ち最初の直線的な電位上昇, それと続いて起る電位変化 の压とんど定常状態を示す部分招よび次の第 2 段の電位 が上昇して数Vの定常状態に達するまでの変化である. 第一段の直線的な電位上昇は溶液中の溶存酸素のうむに は影響されず，季た変化は負荷する電流值飞略々比例す ることおよびこの箐囲ては酸素発生などは行われないこ となどの実験事実から，この範团では負荷される電流は 初期の電極面に括ける蓄電器電流学除いては略々完全に 酸化被膜形成にあずかるものと見なすととができる。そ して電位の変化は形成された酸化被膜の厚さの増加によ る抵抗増加基く $I R$ 降下によってもたらされるすのと


化の様子示した．この図炕おいて電位変化が直線関保 加らはずれて電位変化の平坦部分洋するまでに要する 電気量は，種々の電流密度飞乱いて略々 $10 \mathrm{~m}$. coulomb 附近である。この電気量は形成された酸化被膜を，すで 飞厚い場合のものKついて電子回折的飞確めた Anatase 型の $\mathrm{TiO}_{2}{ }^{(2)}$ と仮定して計算すると, 約 $100 \AA$ の 厚さである.こよで電極面上より酸素ガス発生が起り, 電位変化はゆるやかとなり変化の瓜とんどない状態が現 われる.この電位変化の平坦部分は，見掛け上酸化被膜飞 よる抵抗増加が認められない部分であるが，この範囲で は電極面上よりの酸素ガス発生と同時に, すでに存在し

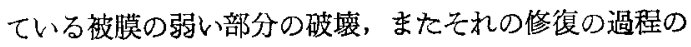
絽返し，或いは酸化物の再結晶などの過程が行われてい るるのと考㝋られる.その後電極面，上の酸化物の成長し や寸い部分を中心として徐々飞被膜が生長し，更飞全面 そわたって膜厚は增加し，第 2 段の電位上昇伴い電位 




第 6 図 $0.1 \mathrm{~N}$ ホウ酸ソーダ中の電気量対電位変化

值飽和甘コウ規準で数 $\mathrm{V}$ 程度に達するものと思われ る、また酸素ガス発生までに生成した被膜については， 肉眼的にそれと認められないが酸素発生後第 2 段の電位 上昇の始まる附近では薄い金色の被膜が認められ，時閶 とともにその濃さを増し数Vに達した附近では青味がか。

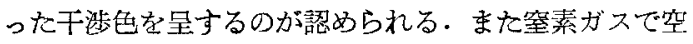
気を置換した溶液に挌いて酸素ガス発生後の第 2 段の電 位上昇部分が空気飽和の溶液の場合より早く行われるの が翀められたが，これは敊そらく電極面よりの酸素ガス 発生の過程の相違飞基づくその後の酸化被膜の形成の速
度に変化を及ぼすものと考えられるがこの機構について はさらに検討の必要があるう。

\section{5. 要約}

チタンの0.1 N ホウ酸ソーダおよびカセイソーダ溶液 に捎ける陽極的挙動について実験を行い次の点を確めた

（1）陽極電位の時間的変化は最初の直線的な電位上 帠を示す部分, それに続く電位変化の緩慢な平坦部括よ びさらに電位の上昇して数Vに達するまでの 3 つの部分 が諗められる。

(2) 途中に現われる電位変化の平坦部は電極面より の酸素発生が行われる点で, その電位と電流の対数は直 線関係を示し，それぞれの溶液に括ける酸素ガス発生の 過電圧を表わす式を求めた。

（3）陽極電位の上昇に酸化被膜形成に上る抵抗増加 に基く $I R$ 降下に上るものと考えられ，陽極電位変化か ら酸化被膜の形成について考察を加えた。

最後に本研究を行うに当りご援助とご的言をいただい た当研究所一宮次長ならでに進藤物理研究室長に深く感 謝いたします。

(昭 33-5-19 受理)

文 献

(1) C.D. Hall, N. Hackerman: J. phys. Chem., 57, 262 (1953)

（2）広田昭一，千菜博，田中隆，野明治婎：㤂用物理，26，651 (1957)

\section{水銀落下膜式電解槽の工業化試験について \\ On the Industrial Operation of the Mercury Falling \\ Film Type Caustic-Chlorine Cell}

渡辺亭**

Tohru WATANABE

\section{1. 緒言}

水平式水銀法食塩電解槽は構造が簡筆で，律造費も安 価であるため広く使用されているが，塩水中の不純物の 許容量が小さい，良䁈の霓解板を必要とする。床面積が 広い，水銀の所要量が多いなどの欠点がある・これらの 欠点を改良した新型電解槽は種々提案されている。筆者 らは特に塩水中の不純物の影響を受けることの少ない水 銀落下膜槽の考案を行い，その予備試験之工業化試験を 行った.

\footnotetext{
* 水銀落下膜式電解䏆化つれて Stadies on the Mercury Falling Film Type Cell

（第1 報） 昭和 29 年 10 月 27 日，電気化学協会秋季大講演会 発表と（第 2 報）昭和 32 年 11 月 29 日，電気化学協会秋孪大講 演会発表を合世て報文とした。

** 日本軽金属株式会社研究所（東京都中央区銀座西 7 丁目 2 番地)
}

塩水中の鉄，マダネシウム，カルシウムなどの不純物 イオンは水銀上に電解析出して，いわゆるアマルガムバ ターをつくる、これは水素過電圧を下げ，塩素ガスの純 度を゙低下させる主原因となる、筆者らの工場の大曹式電 解槽の統計的管理に颃いて，コウ和室の水銀の流速の早 いものは壏素ガスの純位が良いという関係が得られた。 したがって，水銀の流速とアマルガムバターの量との間 に関係があるよう勘すれるので考察を行った。

一般に, コウ和室の筑暗のアマルガム濃度 $A$ は次 武で表わされる。

$$
A=K \cdot I / L \cdot V \cdot \theta
$$

ここに $I$ は電流, $L$ は電槽の巾, $V$ は水銀の流速, $\theta$ は水銀の厚み, $K$ 性例定数である.

水銀上に電解析出した笽水中の不純物が，水銀中にす

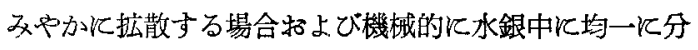

